\title{
Enamel matrix proteins exhibit growth factor activity: A review of evidence at the cellular and molecular levels
}

\author{
MARZENA WYGANOWSKA-ŚWIĄTKOWSKA ${ }^{1}$, PAULINA URBANIAK ${ }^{2}$, \\ MICHAŁ MAREK NOHAWICA ${ }^{3}$, MAŁGORZATA KOTWICKA ${ }^{2}$ and JERZY JANKUN ${ }^{4-6}$ \\ ${ }^{1}$ Department of Conservative Dentistry and Periodontology, Poznan University of Medical Sciences, \\ Poznań 60-820; ${ }^{2}$ Department of Cell Biology, Poznan University of Medical Sciences, Poznań 60-806, Poland; \\ ${ }^{3}$ Dundee Dental School, University of Dundee, Dundee DD1 4HN, UK; ${ }^{4}$ Department of Urology, Urology Research Centre, \\ College of Medicine, University of Toledo, Toledo, OH 43614, USA; ${ }^{5}$ Protein Research Chair, Department of Biochemistry, \\ College of Sciences, King Saud University, Riyadh 11451, Kingdom of Saudi Arabia; ${ }^{6}$ Department of Clinical Nutrition, \\ Medical University of Gdańsk, Gdańsk 80-211, Poland
}

Received December 1, 2014; Accepted March 25, 2015

DOI: $10.3892 /$ etm.2015.2414

\begin{abstract}
Enamel matrix derivative (EMD) is a commercially available protein extract, mainly comprising amelogenins. A number of other polypeptides have been identified in EMD, mostly growth factors, which promote cementogenesis and osteogenesis during the regeneration processes through the regulation of cell proliferation, differentiation and activity; however, not all of their functions are clear. Enamel extracts have been proposed to have numerous activities such as bone morphogenetic protein- and transforming growth factor $\beta$ (TGF- $\beta$ )-like activity, and activities similar to those of insulin-like growth factor, fibroblast growth factor, platelet-derived growth factor, vascular endothelial growth factor and epidermal growth factor. These activities have been observed at the molecular and cellular levels and in numerous animal models. Furthermore, it has been suggested that EMD contains an unidentified biologically active factor that acts in combination with TGF- $\beta 1$, and several studies have reported functional similarities between growth factors and TGF- $\beta$ in cellular processes. The effects of enamel extracts on the cell cycle and biology are summarized and discussed in this review.
\end{abstract}

\section{Contents}

1. Introduction

2. TGF- $\beta$ in the periodontium

Correspondence to: Dr Marzena Wyganowska-Świątkowska, Department of Conservative Dentistry and Periodontology, Poznań University of Medical Sciences, Bukowska 7, Poznań 60-820, Poland E-mail: jerzy.jankun@utoledo.edu

Key words: growth factors, enamel matrix derivative, transforming growth factor- $\beta$, bone morphogenetic protein
3. BMP in the periodontium

4. VEGF in the periodontium

5. PDGF in the periodontium

6. FGF in the periodontium

7. EGF in the periodontium

8. IGF-1 in the periodontium

9. Conclusion

\section{Introduction}

In this review, the growth factor and growth factor-like activities of enamel matrix proteins (EMPs) were examined. Enamel matrix derivative (EMD), a mixture of EMPs, emerged almost two decades ago as an agent capable of periodontal regeneration. Although numerous studies and review papers have been published on this topic, the understanding of the cellular and molecular mechanisms of action of EMD is far from exhaustive (1-7); thus this subject is revisited in the present comprehensive review.

Growth factors regulate important cellular events involved in numerous physiological and pathological processes by binding to specific cell surface receptors (8). A number of polypeptide growth factors have been identified that regulate cell proliferation, chemotaxis or differentiation. Certain growth and differentiation factors, such as insulin-like growth factor 1 (IGF-1), platelet-derived growth factor (PDGF), basic fibroblast growth factor (bFGF), transforming growth factor- $\beta$ (TGF- $\beta$ ) and bone morphogenetic protein (BMP)-2, are able to stimulate the cellular activities associated with periodontal regeneration in periodontal ligament (PDL) cells (9-19).

Ameloblasts synthesize and secrete a number of EMPs, including amelogenins, ameloblastin, amelotin, tuftelin and enamelin $(20,21)$. EMPs are associated with the process of amelogenesis and they play a crucial role in the formation of enamel and periodontal attachment during tooth development; however, in wound healing and tissue regeneration EMPs show several novel functions. 
Clinically, EMPs are applied as an extract of porcine fetal tooth enamel matrix (known as EMD) for the periodontal regeneration of teeth affected by periodontitis, root coverage procedures and tooth implantation. EMD has also been used in in vitro research, for dentin repair, tooth movement, anti-cancer treatment evaluation and skin wound healing (22). The regeneration of several types of periodontal tissue, including alveolar bone, cellular cementum and collagenous ligaments, and the formation of an extracellular matrix (ECM) layer in adjacent tissues has been observed following EMD application (22). The predominant (>90\%) component of EMD is amelogenin, which in its native form is slowly degraded by the proteinases enamelysin and kallikrein-4 (20). Cleavage produces different, shorter forms of amelogenin. These amelogenin-derived peptides are classified into two groups: Leucine-rich amelogenin peptide (LRAP) and tyrosine-rich amelogenin peptide (TRAP) (Fig. 1). While EMD presents a number of growth factor-like effects, it is the TGF- $\beta$ activity that is predominately known (23-26). EMD has also been reported to contain other cytokines, such as a BMP-like growth factor and bone sialoprotein (BSP)-like molecules $(27,28)$.

To date, which of the EMD fractions are crucial for BMPor TGF- $\beta$-like activity has not been definitively clarified. In one study, the chromatographic separation of EMD resulted in 22 protein fractions. Fractions 4-6 had BMP-like activity while fractions 8-13 had TGF- $\beta$-like activity, and fractions 4-13 were found to contain 10-25-kDa peptides (26). It was observed that BMP-2 signal transduction activity was inhibited by authentic TGF- $\beta 1$ and the TGF- $\beta 1$ or TGF- $\beta$-like activity in an EMD gel, but that signal transduction by TGF- $\beta$ was not suppressed by BMP-2. It was hypothesized that TGF- $\beta$ could not completely inhibit the activity of BMP, since BMP and TGF- $\beta$ activate SMAD intracellular transcription factors (26). In oral epithelial cells and fibroblasts isolated from gingiva, EMD stimulated the rapid translocation of SMAD2 protein from the cytoplasm to the cell nucleus, which suggests the involvement of TGF- $\beta$-like factors (24).

\section{TGF- $\beta$ in the periodontium}

TGF- $\beta$ is a member of the TGF- $\beta$ superfamily, which consists of five isoforms of TGF- $\beta$ and associated homologous proteins including activins, inhibins, BMPs, growth differentiation factors and the glial cell line-derived neurotrophic factor family (29-31). These structurally related polypeptides are characterized by the presence of a common sequence and specifically positioned structures, namely a 'cystine knot' composed of six cysteine residues (32). The structural differences between the TGF- $\beta$ proteins and the BMPs have been found to lie within four regions of the polypeptide chain. These are the $\mathrm{N}$-terminal segment, the loops at the end of fingers 1 and 2 and the C-terminus of helix $\alpha 3$ (33). In addition, the receptor activation differs, despite the fact that in each case it involves the recruitment of pairs of type I and type II receptor molecules by dimeric ligands to form signaling complexes. Sequential binding is typical of TGF- $\beta$ and activin ligand receptors, while a fully cooperative interaction is characteristic of BMP ligand receptors (33). Mature TGF- $\beta$ is a homodimer, composed of two 12.5-kDa polypeptides joined by a disulfide bond between two cysteine 77 residues and by hydrophobic interactions (34).
TGF- $\beta$ regulates various cellular processes including cell growth, apoptosis, homeostasis, differentiation, migration, wound healing, fibrosis, angiogenesis and carcinogenesis (35-37). TGF- $\beta 1$ has been indicated to play an important role in the modulation of tissue formation and development of the periodontium (38). It is also a transcription-regulating factor $(29,30,39,40)$. Notably, the response can differ considerably according to the type of cell and the stimulation context, even though the activation is induced by the same receptor. It is, therefore, critical, particularly in carcinogenesis, to know where TGF- $\beta$ may act as a suppressor and where as a stimulator. The role of TGF- $\beta$ in carcinogenesis appears to involve a signaling pathway involving SMAD proteins, which is induced by TGF- $\beta$ (41). Non-SMAD signaling pathways in TGF- $\beta$ signaling include extracellular signal-regulated kinases (ERK), c-Jun N-terminal kinases (JNK), Rho-associated protein kinases and P21-activated kinase-2, depending on the cell line (42). It has been suggested that TGF- $\beta$-mediated apoptosis is regulated by the modulation of SMAD activation (43). Furthermore, TGF- $\beta$ has been indicated to participate in carcinogenesis by immune suppression (44). Several studies have indicated that TGF- $\beta$ arrests growth in the majority of cell types $(29,45)$. This effect has been observed in primary embryonic fibroblasts; however, in fibroblasts from SMAD3-null mice, the growth inhibitory effect of TGF- $\beta$ was suppressed (45).

Several studies of EMD have demonstrated that it contains TGF- $\beta 1$ or a TGF- $\beta$-like substance, and that EMD rapidly translocates SMAD2, an effector of the TGF- $\beta$ signaling pathway, into the nucleus and modulates the proliferation of human gingival fibroblasts and oral epithelial cells in a cell type-specific manner $(24,26,46,47)$. Furthermore, experiments in vitro on epithelial and fibroblastic cells with anti-TGF- $\beta$ antibodies, in which the TGF- $\beta 1$-induced SMAD2 translocation was blocked, showed that the EMD-induced translocation of SMAD2 was strongly reduced. This may indicate that they act via the same mechanism (48). In human PDL fibroblasts, EMD stimulated the release of TGF- $\beta 1$ (45). PDL cell metabolism was significantly increased when EMD was present in cultures, and an increased autocrine production of TGF- $\beta 1$, interleukin 6 (IL-6) and PDGF-AB was detected when compared with that in control cultures (49).

It has been postulated that EMD may contain an additional mitogenic factor, which acts in combination with TGF- $\beta 1$ to fully stimulate fibroblastic proliferation. Kawase et al (46) investigated the effects of EMD, TGF- $\beta 1$ and neutralizing TGF- $\beta$ antibody on epithelial and fibroblastic cells. It was found that porcine EMD translocated SMAD2 into the nucleus of cells, as does TGF- $\beta 1$ or a TGF- $\beta$-like substance. SMAD2 is an effector of the TGF- $\beta$ signaling pathway that modulates the proliferation of gingival fibroblastic and oral epithelial cells. In the study, cells were treated with porcine TGF- $\beta 1$ in order to compare its actions with those of EMD. In the epithelial and fibroblastic cells, TGF- $\beta 1$ replicated the action of EMD in the nuclear accumulation of SMAD2, the phosphorylation of mitogen activated protein (MAP) kinase family members and, consequently, cell growth induction. Neutralizing TGF- $\beta$ antibody blocked certain actions of EMD. The anti-TGF- $\beta$ antibody prevented TGF- $\beta 1$-induced SMAD2 translocation and blocked other actions of EMD, such as p38-MAP kinase 


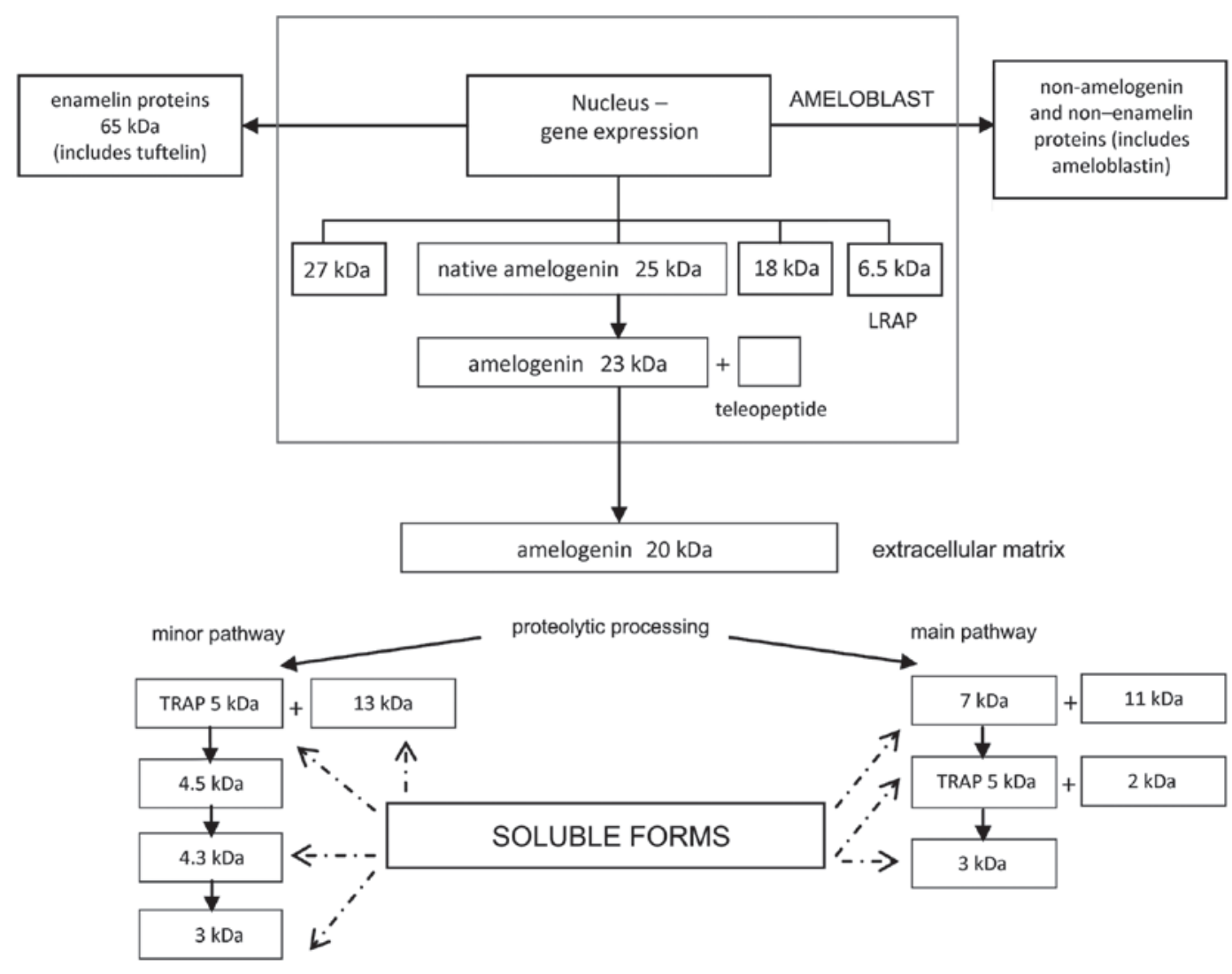

Figure 1. Extracellular amelogenin proteolytic process. Ameloblasts synthesize three categories of enamel matrix protein: Amelogenin, enamelin and a non-amelogenin non-enamelin group. Amelogenin is slowly degraded by specific extracellular proteolytic enzymes to smaller soluble forms. LRAP, leucine-rich amelogenin peptide; TRAP, tyrosine-rich amelogenin peptide.

phosphorylation and p21WAF1/cip1 expression in epithelial cells. It has been suggested that TGF- $\beta 1$ or a TGF- $\beta$-like substance is a principal bioactive factor in EMD, but the TGF- $\beta 1$-neutralizing antibody did not block EMD-induced fibroblast proliferation, strongly implying that EMD contains unidentified mitogenic factor(s).

The effects of EMD vary according to the origin of the cell line; EMD has been found to increase the proliferation of gingival fibroblasts but decrease the proliferation of epithelial cells $(50,51)$. Notably, no apoptotic effect was observed when epithelial cells were treated with EMD (51), which led to the conclusion that EMD acted as a cytostatic rather than a cytotoxic agent for epithelial cells. EMD has also been demonstrated to have a growth-inhibitory effect on epithelial (HeLa) cells and human squamous cell carcinoma-derived-25 cells (51). Kawase et al (46) postulated that EMD reduced DNA synthesis, suggesting that a reduction in epithelial cell growth could be mediated by TGF- $\beta$-like activity. EMD and TGF- $\beta$ are also able to stimulate the production of matrix metalloproteinases (MMPs), which are crucial in tumorigenesis and in benign keratinocytes (27).

The findings concerning the effect of EMD on the other special epithelial cells, endothelial cells, which are required for the healing and regeneration of periodontal tissue, are contradictory and include either a stimulatory effect (52) or no effect at all (53) on proliferation. A low concentration of EMD stimulated the proliferation and migration of endothelial cells, whereas a higher concentration inhibited them (54). It was hypothesized that TGF- $\beta$ present in the EMD-conditioned media may be responsible for the effects of EMD on the proliferation and viability of human umbilical vein endothelial cells (54).

The effect of EMD is also dependent upon its specific fraction. Full-length amelogenin molecules have been shown to stimulate the autocrine production of BMP, while smaller fractions like LRAP and TRAP stimulate the autocrine production of TGF- $\beta$ in the human PDL (4). The TGF- $\beta$ protein, however, has not been found in the composition of EMD (50). The aforementioned studies suggest that specific amelogenin molecules may stimulate the autocrine release of growth factors that coordinate the regenerative effects of EMD.

\section{BMP in the periodontium}

BMPs belong to the TGF- $\beta$ superfamily of growth factors (55) but have two extra domains in addition to the structure typical of the TGF family members TGF- $\beta$, activin/inhibin and nodal. The family of BMPs is particularly noteworthy due to its function in the morphogenesis and development of various tissues, cell proliferation, apoptosis and ECM protein synthesis, as well as its ability to induce cartilage and bone formation (56-59). BMP-2, - 4, -6 and -7 have osteoinductive activities in vivo (60) whereas other BMPs exhibit low osteoinductive activity but modulate BMP action (57). BMP-2 and -4 are also naturally expressed in the skin, in epidermal keratinocytes and dermal fibroblasts $(61,62)$. In addition, they induce embryonic stem cells 
into chondrogenic differentiation (63). The function of BMP-2 extends to affecting the production of ECM, since it stimulates the production of glycosaminoglycan and collagen type II (64). It acts through influencing the balance between MMP2 and its inhibitor, tissue inhibitor of metalloproteinase-2 (65), as well as via the classical SMAD pathway through which it can co-interact with FGF and VEGF (66-68).

BMPs bind to BMP receptors of types I and II. Type I receptors include activin receptor-like kinase (ALK)-2, ALK-3 (BMP receptor IA; expressed in most types of cells) and ALK-6 (BMP receptor IB; chondrocytes and osteoclasts express only this type of BMP receptor), and mainly determine the specificity of the intracellular signals. Type II receptors include BMP type II receptor, activin type II receptor and activin type IIB receptor. BMPs activate intracellular transcription factors SMAD-1, -5 and -8 , which dimerize with SMAD-4 prior to translocation into the nucleus (67,69-71). Osteopontin, osteoprotegerin (OPG), BMP-7 and SMAD-1 are activated by BMP through the SMAD activation mechanism (72-74). BMPs also stimulate MAP kinase, phosphoinositide-3 kinase and JNK by SMAD-independent signals $(75,76)$.

In the periodontium the presence of BMP-2 and BMP-4 between sections of human periodontal structures is distinct. Immunohistochemistry has shown intense staining in the PDL with almost no detection in the cementum, alveolar bone and gingival connective tissue (77). This finding did not correlate with the expression of mRNA for these proteins. In vitro the gingival and PDL fibroblasts expressed mRNA for BMP-2 and -4 , and while the BMP- 4 mRNA level was similar in the gingival and periodontal fibroblasts, the BMP-2 expression was higher in the gingival fibroblasts (77).

EMD has been shown to contain or stimulate growth factors such as TGF- $\beta$, BMP-2, -4 and $-7(24,26,78-80)$. It has also been noted that amelogenin stimulates BSP gene transcription in osteoblasts by inducing the expression of nuclear proteins that bind to FGF-2 response elements and TGF- $\beta 1$ activation elements in BSP gene promoters (4). Amelogenin has comparable osteogenic activities to recombinant human BMP-2 and induces the formation of a reparative dentin bridge, in a manner comparable with that of BMP-7 and calcium hydroxide (81). In response to EMD treatment, human dental follicle cells have exhibited increased expression levels of BMP-2, BMP-7, BSP and two cementum markers, namely cementum attachment protein and cementum protein-23 (78).

The investigation of osteoprogenitor cells (C2C12) and human microvascular endothelial cells showed that noggin, a molecule that prevents BMPs from binding to their receptors $(82,83)$, abolishes alkaline phosphatase activity in $\mathrm{C} 2 \mathrm{C} 12$ cells. This suggests that the effect on osteoprogenitor cell differentiation results from the action of BMP-like proteins, whereas the effects on proliferation and angiogenesis are associated with lower molecular weight proteins from EMD (84). By contrast, the osteoinductive activity of LRAP has been found to be comparable with the effect of BMP-2 on the osteogenesis of mouse embryonic stem cells (85).

\section{VEGF in the periodontium}

VEGF induces endothelial proliferation, migration and specialization in new and developing vascular beds (86) during embryogenesis and later development, wound healing and menstruation. It is also a potent promoter of angiogenesis in numerous types of tumors (87), diabetes, rheumatoid fever and psoriasis (88).

In the periodontium, VEGF has been shown to be involved in the regulation of bone remodeling by attracting endothelial cells and osteoclasts and by stimulating osteoblast differentiation (89). VEGF has been found in a higher concentration in crevicular fluid during gingivitis (90). Angiogenesis is central to tissue healing. EMD, directly or indirectly, positively influences this process. EMD has been shown to have a chemotactic effect on endothelial cells in vitro (53) and to stimulate human microvascular endothelial cells (HMVECs) as well as their production of VEGF $(52,84)$. Additionally, EMD enhances the communication between HMVECs and PDL fibroblasts (52). Human periodontal and dermal fibroblasts cultured with EMD also exhibit increased VEGF production $(52,91)$. One of the possible mechanisms by which EMD stimulates angiogenesis is by increasing the expression of MMP-2 in human microvascular pericytes $(91,92)$. Another route could be through the EMD-induced stimulation of VEGF production, which occurs partially via TGF- $\beta 1$ and FGF-2 in human gingival fibroblasts (37). It is notable that EMD and its major component, amelogenin, stimulate angiogenesis but the small tyrosine-rich and leucine-rich polypeptides present in a $5-\mathrm{kD}$ protein fraction derived from EMD do not (93). This stimulation is dose-dependent (94). At low concentrations EMD stimulates PDL fibroblast proliferation by HMVECs but in higher concentrations it does not (52).

\section{PDGF in the periodontium}

PDGF stimulates the activation of proliferation, migration and matrix synthesis in gingival and PDL fibroblasts, cementoblasts, pre-osteoblasts and osteoblasts in a dose- and time-dependent manner (15,95-100). It is suggested that during wound healing, PDGF cooperates with other growth factors, such as IGF-1 (101), TGF- $\beta$ (99) or VEGF (102). PDGF has VEGF-like effects on angiogenesis. The three main VEGF receptors are structurally similar to the family of PDGF receptor III class of tyrosine kinase receptors (RTK class III) (103). The RTK-ERK 1/2 signaling pathway induced by EMD is similar to that activated by epidermal growth factor (EGF) (103). PDGF upregulates the expression of integrin collagen receptors in rat fibroblasts (104) and also stimulates actin filament reorganization in cytoskeletal proteins (105). EMD induces PDL fibroblasts to secrete TGF- $\beta 1$, IL- 6 and PDGF-AB by intracellular cyclic adenosine monophosphate signaling; epithelial cell growth is inhibited by the same signal (49). A combination of EMD and PDGF-BB produced greater proliferative and wound-fill effects on PDL cells than either protein by itself (106).

\section{FGF in the periodontium}

FGF acts as a mitogen for vascularization during organogenesis $(107,108)$. FGF is specifically upregulated in bone marrow stromal stem cell transplants, and may play important roles in the growth of blood vessels and in the recruitment of hematopoietic elements $(109,110)$. Additionally, the actions of bFGF 
and VEGF are complementary and when present together may result in a synergistic effect on angiogenesis (111-113), which may involve enhanced cytoprotection against complement-mediated vascular injury (114). It has been indicated that FGF-2 promotes valve interstitial cell wound repair through the TGF- $\beta /$ SMAD-2 and -3 signaling pathway (115). EMD has been observed to increase the expression of FGF-2 and TGF- $\beta 1$ in osteoblasts (116). FGF-2 stimulates the proliferation of osteoblastic cells but reduces their differentiation; therefore, EMD may modify cell proliferation and differentiation via FGF-2 production $(117,118)$. EMD potentially induces FGF-2 via prostaglandin-2 production, decreases the expression of MMP-1 via FGF-2 (119) and modulates FGF-2 gene expression in osteoblasts and Müller cells $(120,121)$. In smooth muscle cells, FGF-2 induces the expression of MMP-1 protein and inhibits collagen synthesis (122). The cooperative effects of FGF-2 and VEGF have also been explored in periodontal ligament cells (123).

\section{EGF in the periodontium}

EGF enhances the cellular proliferation and differentiation of epidermal and epithelial cells, fibroblasts, cartilage and bone-derived cells during growth, maturation and healing processes (124-129), and is also a potent mitogenic factor (130-132). The treatment of human gingival fibroblasts with EMD results in an autocrine/paracrine EGF receptor (EGFR) transactivation. There are two suggested independent mechanisms of EGFR transactivation: i) An intracellular pathway mediated by the src family of non-receptor tyrosine kinases $(133,134)$; and ii) an extracellular pathway mediated by the shedding of a transmembrane pro-form of EGFR ligands by metalloproteinases (135-137). The capacity of PDL cells to bind to EGF and EMD has been assessed in a ${ }^{125}$ I-EGF radioligand binding assay. The assay showed that there was no significant competitive binding between EGF and EMD, indicating that the EGFR is not the binding site for EMD (103). These results indicate that EMD does not contain biologically effective amounts of EGF and supports a study in which no EGF was detected in EMD by radioimmunoassay (50). Other studies have demonstrated cross-talk between TGF- $\beta$ and EGF-stimulated pathways (138) and suggested that the molecular mechanisms by which TGF- $\beta 1$ and EGF interact to elicit these phenotypic changes may involve MAP kinases, SMADs, activator protein and upstream stimulatory factor transcription factors $(139,140)$.

\section{IGF-1 in the periodontium}

IGF-1 is a multifunctional peptide that regulates growth, differentiation and the expression of ECM proteins (9). It is also thought to be a key mediator of wound healing, inducing epithelial and mesenchymal cell proliferation (8). IGF is reported to stimulate cell migration $(126,130,132)$ and has been successfully used for dentine-pulp complex regeneration (141). EMD stimulates IGF-1, TGF- $\beta 1$, PDGF and IL-6 production in PDL fibroblasts $(49,142)$; however, it has no effect on IGF-1, BMP-2 or IL-6 in HeLa and MG-63 cell lines $(49,143)$. PDGF and IGF together synergistically enhance gingival fibroblast contractility, and may have had a synergistic effect on wound healing $(101,144)$. Furthermore, cementum-derived growth factor (CGF) has been characterized as an IGF-1-like molecule (145). CGF has been shown to be mitogenic for both PDL and gingival fibroblasts, to promote the migration and growth of progenitor cells adjacent to the dentin matrix, and to participate in their differentiation into cementoblasts (146).

\section{Conclusion}

The effects of EMD on periodontal tissue regeneration have been well documented, however, the mechanism of action remains unknown. To date, no receptors specific for amelogenin have been identified, to the best of our knowledge. However, there are putative receptors, such as lysosomal-associated membrane proteins (LAMP); LAMP-1 interacts with LRAP, and LAMP-3 with longer amelogenin protein isoforms. Notably, neither of these receptors interacts with both of the amelogenin molecules (147). The role of amelogenin derivatives in the periodontium is also unclear. Studies carried out on LRAP have shown its induction effect on the expression of bone acidic glycoprotein-75, BSP (148) and OPG in mineralized tissues, including cementoblasts (149). When evaluating whether the action of EMD on cells is dependent on direct cell-matrix contact or mediated by growth factors released from EMD or stimulated by it, the close interaction between growth factors presents a challenge. It has been suggested that the soluble growth factors contained in EMD may be responsible for the stimulating effects. TGF- $\beta$ and small amelogenin peptides are potential candidates for the factors mediating the action of EMD (150), however further studies are required to investigate this further.

\section{Acknowledgements}

This study was supported in part by grants from the Polish Ministry of Science (no. 403283040), the Frank Stranahan Endowed Chair and the Children Miracle Network.

\section{References}

1. Bosshardt DD: Biological mediators and periodontal regeneration: a review of enamel matrix proteins at the cellular and molecular levels. J Clin Periodontol 35 (Suppl): 87-105, 2008.

2. Gibson CW: The amelogenin 'enamel proteins' and cells in the periodontium. Crit Rev Eukaryot Gene Expr 18: 345-360, 2008.

3. Grandin HM, Gemperli AC and Dard M: Enamel matrix derivative: a review of cellular effects in vitro and a model of molecular arrangement and functioning. Tissue Eng Part B Rev 18: 181-202, 2012.

4. Lyngstadaas SP, Wohlfahrt JC, Brookes SJ, Paine ML, Snead ML and Reseland JE: Enamel matrix proteins; old molecules for new applications. Orthod Craniofac Res 12: 243-253, 2009.

5. Miron RJ, Guillemette V, Zhang Y, Chandad F and Sculean A: Enamel matrix derivative in combination with bone grafts: A review of the literature. Quintessence Int 45: 475-487, 2014.

6. Rathe F, Junker R, Chesnutt BM and Jansen JA: The effect of enamel matrix derivative (Emdogain) on bone formation: a systematic review. Tissue Eng Part B Rev 15: 215-224, 2009.

7. Zeichner-David M: Is there more to enamel matrix proteins than biomineralization? Matrix Biol 20: 307-316, 2001.

8. Giannobile WV: Periodontal tissue engineering by growth factors. Bone 19 (Suppl): 23S-37S, 1996.

9. Blom S, Holmstrup P and Dabelsteen E: The effect of insulin-like growth factor-I and human growth hormone on periodontal ligament fibroblast morphology, growth pattern, DNA synthesis and receptor binding. J Periodontol 63: 960-968, 1992. 
10. Brady TA, Piesco NP, Buckley MJ, Langkamp HH, Bowen LL and Agarwal S: Autoregulation of periodontal ligament cell phenotype and functions by transforming growth factor-beta1. J Dent Res 77: 1779-1790, 1998.

11. Dennison DK, Vallone DR, Pinero GJ, Rittman B and Caffesse RG: Differential effect of TGF-beta 1 and PDGF on proliferation of periodontal ligament cells and gingival fibroblasts. J Periodontol 65: 641-648, 1994.

12. Kobayashi M, Takiguchi T, Suzuki R, et al: Recombinant human bone morphogenetic protein-2 stimulates osteoblastic differentiation in cells isolated from human periodontal ligament. J Dent Res 78: 1624-1633, 1999.

13. Lynch SE, Williams RC, Polson AM, et al: A combination of platelet-derived and insulin-like growth factors enhances periodontal regeneration. J Clin Periodontol 16: 545-548, 1989.

14. Matsuda N, Lin WL, Kumar NM, Cho MI and Genco RJ: Mitogenic, chemotactic and synthetic responses of rat periodontal ligament fibroblastic cells to polypeptide growth factors in vitro. J Periodontol 63: 515-525, 1992.

15. Nishimura F and Terranova VP: Comparative study of the chemotactic responses of periodontal ligament cells and gingival fibroblasts to polypeptide growth factors. J Dent Res 75: 986-992, 1996.

16. Oates TW, Rouse CA and Cochran DL: Mitogenic effects of growth factors on human periodontal ligament cells in vitro. J Periodontol 64: 142-148, 1993.

17. Takayama S, Murakami S, Miki Y, et al: Effects of basic fibroblast growth factor on human periodontal ligament cells. J Periodontal Res 32: 667-675, 1997.

18. Terranova VP, Odziemiec C, Tweden KS and Spadone DP: Repopulation of dentin surfaces by periodontal ligament cells and endothelial cells. Effect of basic fibroblast growth factor. J Periodontol 60: 293-301, 1989.

19. Terranova VP and Wikesjö UM: Extracellular matrices and polypeptide growth factors as mediators of functions of cells of the periodontium. A review. J Periodontol 58: 371-380, 1987.

20. Bartlett JD and Simmer JP: Proteinases in developing dental enamel. Crit Rev Oral Biol Med 10: 425-441, 1999.

21. Margolis HC, Beniash E and Fowler CE: Role of macromolecular assembly of enamel matrix proteins in enamel formation. J Dent Res 85: 775-793, 2006.

22. Sculean A, Schwarz F, Becker J and Brecx M: The application of an enamel matrix protein derivative (Emdogain) in regenerative periodontal therapy: a review. Med Princ Pract 16: 167-180, 2007.

23. Heijl L, Heden G, Svärdström G and Ostgren A: Enamel matrix derivative (EMDOGAIN) in the treatment of intrabony periodontal defects. J Clin Periodontol 24: 705-714, 1997.

24. Kawase T, Okuda K, Momose M, Kato Y, Yoshie H and Burns DM: Enamel matrix derivative (EMDOGAIN) rapidly stimulates phosphorylation of the MAP kinase family and nuclear accumulation of smad 2 in both oral epithelial and fibroblastic human cells. J Periodontal Res 36: 367-376, 2001.

25. Petinaki E, Nikolopoulos S and Castanas E: Low stimulation of peripheral lymphocytes, following in vitro application of Emdogain. J Clin Periodontol 25: 715-720, 1998.

26. Suzuki S, Nagano T, Yamakoshi Y, et al: Enamel matrix derivative gel stimulates signal transduction of BMP and TGF- $\beta$. J Dent Res 84: 510-514, 2005.

27. Laaksonen M, Sorsa T and Salo T: Emdogain in carcinogenesis: a systematic review of in vitro studies. J Oral Sci 52: 1-11, 2010.

28. Nikolopoulos S, Peteinaki E and Castanas E: Immunologic effects of emdogain in humans: one-year results. Int $\mathrm{J}$ Periodontics Restorative Dent 22: 269-277, 2002.

29. Massagué J, Blain SW and Lo RS: TGFbeta signaling in growth control, cancer, and heritable disorders. Cell 103: 295-309, 2000.

30. Patterson GI and Padgett RW: TGF beta-related pathways. Roles in Caenorhabditis elegans development. Trends Genet 16: 27-33, 2000.

31. Roberts AB, Sporn MB, Assoian RK, et al: Transforming growth factor type beta: rapid induction of fibrosis and angiogenesis in vivo and stimulation of collagen formation in vitro. Proc Natl Acad Sci USA 83: 4167-4171, 1986.

32. Sun PD and Davies DR: cccccccccccc. Annu Rev Biophys Biomol Struct 24: 269-291, 1995

33. Innis CA, Shi J and Blundell TL: Evolutionary trace analysis of TGF-beta and related growth factors: implications for site-directed mutagenesis. Protein Eng 13: 839-847, 2000.
34. Daopin S, Piez KA, Ogawa Y and Davies DR: Crystal structure of transforming growth factor-beta 2: an unusual fold for the superfamily. Science 257: 369-373, 1992

35. Gruber R, Roos G, Caballé-Serrano J, Miron R, Bosshardt DD and Sculean A: TGF- $\beta$ RI kinase activity mediates Emdogain-stimulated in vitro osteoclastogenesis. Clin Oral Investig 18: 1639-1646, 2014.

36. Gruber R, Bosshardt DD, Miron RJ, Gemperli AC, Buser D and Sculean A: Enamel matrix derivative inhibits adipocyte differentiation of 3T3-L1 cells via activation of TGF- $\beta$ RI kinase activity. PloS One 8: e71046, 2013.

37. Sakoda K, Nakajima Y and Noguchi K: Enamel matrix derivative induces production of vascular endothelial cell growth factor in human gingival fibroblasts. Eur J Oral Sci 120: 513-519, 2012

38. Gao J, Symons AL and Bartold PM: Expression of transforming growth factor-beta 1 (TGF-beta1) in the developing periodontium of rats. J Dent Res 77: 1708-1716, 1998.

39. Akhurst RJ and Derynck R: TGF-beta signaling in cancer-a double-edged sword. Trends Cell Biol 11 (Suppl): S44-S51, 2001

40. Ten Dijke P, Goumans MJ, Itoh F and Itoh S: Regulation of cell proliferation by Smad proteins. J Cell Physiol 191: 1-16, 2002.

41. Lampropoulos P, Zizi-Sermpetzoglou A, Rizos S, Kostakis A, Nikiteas N and Papavassiliou AG: TGF-beta signalling in colon carcinogenesis. Cancer Lett 314: 1-7, 2012.

42. Blanchette F, Rivard N, Rudd P, Grondin F, Attisano L and Dubois CM: Cross-talk between the p42/p44 MAP kinase and Smad pathways in transforming growth factor beta 1-induced furin gene transactivation. J Biol Chem 276: 33986-33994, 2001.

43. Jang CW, Chen CH, Chen CC, Chen JY, Su YH and Chen RH: TGF-beta induces apoptosis through Smad-mediated expression of DAP-kinase. Nat Cell Biol 4: 51-58, 2002.

44. Rahimi RA and Leof EB: TGF- $\beta$ signaling: A tale of two receptors. J Cell Biochem 102: 593-608, 2007.

45. Datto MB, Frederick JP, Pan L, Borton AJ, Zhuang Y and Wang XF: Targeted disruption of Smad3 reveals an essential role in transforming growth factor beta-mediated signal transduction. Mol Cell Biol 19: 2495-2504, 1999.

46. Kawase T, Okuda K, Yoshie H and Burns DM: Anti-TGF-beta antibody blocks enamel matrix derivative-induced upregulation of p21WAF1/cip1 and prevents its inhibition of human oral epithelial cell proliferation. J Periodontal Res 37: 255-262, 2002.

47. Wada Y, Yamamoto H, Nanbu S, Mizuno M and Tamura M: The suppressive effect of enamel matrix derivative on osteocalcin gene expression of osteoblasts is neutralized by an antibody against TGF-beta. J Periodontol 79: 341-347, 2008.

48. Vayalil PK, Iles KE, Choi J, Yi AK, Postlethwait EM and Liu RM: Glutathione suppresses TGF-beta-induced PAI-1 expression by inhibiting p38 and JNK MAPK and the binding of AP-1, SP-1 and Smad to the PAI-1 promoter. Am J Physiol Lung Cell Mol Physiol 293: L1281-L1292, 2007.

49. Lyngstadaas SP, Lundberg E, Ekdahl H, Andersson C and Gestrelius S: Autocrine growth factors in human periodontal ligament cells cultured on enamel matrix derivative. J Clin Periodontol 28: 181-188, 2001.

50. Gestrelius S, Andersson C, Lidström D, Hammarström L and Somerman M: In vitro studies on periodontal ligament cells and enamel matrix derivative. J Clin Periodontol 24: 685-692, 1997.

51. Kawase T, Okuda K, Yoshie H and Burns DM: Cytostatic action of enamel matrix derivative (EMDOGAIN) on human oral squamous cell carcinoma-derived SCC25 epithelial cells. J Periodontal Res 35: 291-300, 2000.

52. Schlueter SR, Carnes DL Jr and Cochran DL: In vitro effects of enamel matrix derivative on microvascular cells. J Periodontol 78: 141-151, 2007.

53. Yuan K, Chen CL and Lin MT: Enamel matrix derivative exhibits angiogenic effect in vitro and in a murine model. J Clin Periodontol 30: 732-738, 2003.

54. Bertl K, An N, Bruckmann C, et al: Effects of enamel matrix derivative on proliferation/viability, migration and expression of angiogenic factor and adhesion molecules in endothelial cells in vitro. J Periodontol 80: 1622-1630, 2009.

55. Wozney JM, Rosen V, Celeste AJ, et al: Novel regulators of bone formation: molecular clones and activities. Science 242: 1528-1534, 1988.

56. Bragdon B, Moseychuk O, Saldanha S, King D, Julian J and Nohe A: Bone morphogenetic proteins: a critical review. Cell Signal 23: 609-620, 2011. 
57. Chen D, Zhao M, Harris SE and Mi Z: Signal transduction and biological functions of bone morphogenetic proteins. Front Biosci 9: 349-358, 2004.

58. Hogan BL: Bone morphogenetic proteins: multifunctional regulators of vertebrate development. Genes Dev 10: 1580-1594, 1996.

59. Wordinger RJ and Clark AF: Bone morphogenetic proteins and their receptors in the eye. Exp Biol Med (Maywood) 232: 979-992, 2007.

60. Ogata T, Wozney JM, Benezra R and Noda M: Bone morphogenetic protein 2 transiently enhances expression of a gene, Id (inhibitor of differentiation), encoding a helix-loop-helix molecule in osteoblast-like cells. Proc Natl Acad Sci USA 90 9219-9222, 1993.

61. Myllylä RM, Haapasaari KM, Palatsi R, et al: Multiple miliary osteoma cutis is a distinct disease entity: four case reports and review of the literature. Br J Dermatol 164: 544-552, 2011.

62. Plikus MV, Mayer JA, de la Cruz D, et al: Cyclic dermal BMP signalling regulates stem cell activation during hair regeneration. Nature 451: 340-344, 2008

63. Kramer J, Hegert C, Guan K, Wobus AM, Müller PK and Rohwedel J: Embryonic stem cell-derived chondrogenic differentiation in vitro: activation by BMP-2 and BMP-4. Mech Dev 92: 193-205, 2000.

64. Rui YF, Du L, Wang Y, et al: Bone morphogenetic protein 2 promotes transforming growth factor $\beta 3$-induced chondrogenesis of human osteoarthritic synovium-derived stem cells Chin Med J (Engl) 123: 3040-3048, 2010.

65 . Hu J, Cui D, Yang X, et al: Bone morphogenetic protein-2: a potential regulator in scleral remodeling. Mol Vis 14 2373-2380, 2008

66. Blanco Calvo M, Bolós Fernández V, Medina Villaamil V, Aparicio Gallego G, Díaz Prado S and Grande Pulido E: Biology of BMP signalling and cancer. Clin Transl Oncol 11: 126-137, 2009

67. Miyazono K, Maeda S and Imamura T: BMP receptor signaling: transcriptional targets, regulation of signals and signaling cross-talk. Cytokine Growth Factor Rev 16: 251-263, 2005.

68. Ryoo HM, Lee MH and Kim YJ: Critical molecular switches involved in BMP-2-induced osteogenic differentiation of mesenchymal cells. Gene 366: 51-57, 2006.

69. Holtzhausen A, Golzio C, How T, et al: Novel bone morphogenetic protein signaling through $\mathrm{Smad} 2$ and $\mathrm{Smad} 3$ to regulate cancer progression and development. FASEB J 28: 1248-1267, 2014.

70. Matsumoto Y, Otsuka F, Hino J, et al: Bone morphogenetic protein-3b (BMP-3b) inhibits osteoblast differentiation via Smad2/3 pathway by counteracting Smad1/5/8 signaling. Mol Cell Endocrinol 350: 78-86, 2012.

71. Nohe A, Keating E, Knaus P and Petersen NO: Signal transduction of bone morphogenetic protein receptors. Cell Signal 16: 291-299, 2004.

72. Hullinger TG, Pan Q, Viswanathan HL and Somerman MJ: TGFbeta and BMP-2 activation of the OPN promoter: roles of smad- and hox-binding elements. Exp Cell Res 262: 69-74, 2001.

73. Stopa M, Anhuf D, Terstegen L, Gatsios P, Gressner AM and Dooley S: Participation of Smad2, Smad3 and Smad4 in transforming growth factor beta (TGF-beta)-induced activation of Smad7. THE TGF-beta response element of the promoter requires functional Smad binding element and E-box sequences for transcriptional regulation. J Biol Chem 275: 29308-29317, 2000.

74. Wan M, Shi X, Feng X and Cao X: Transcriptional mechanisms of bone morphogenetic protein-induced osteoprotegrin gene expression. J Biol Chem 276: 10119-10125, 2001.

75. Guicheux J, Lemonnier J, Ghayor C, Suzuki A, Palmer G and Caverzasio J: Activation of $\mathrm{p} 38$ mitogen-activated protein kinase and c-Jun-NH2-terminal kinase by BMP-2 and their implication in the stimulation of osteoblastic cell differentiation. J Bone Miner Res 18: 2060-2068, 2003.

76. Osyczka AM and Leboy PS: Bone morphogenetic protein regulation of early osteoblast genes in human marrow stroma cells is mediated by extracellular signal-regulated kinase and phosphatidylinositol 3-kinase signaling. Endocrinology 146: 3428-3437, 2005

77. Ivanovski S, Li H, Haase HR and Bartold PM: Expression of bone associated macromolecules by gingival and periodontal ligament fibroblasts. J Periodontal Res 36: 131-141, 2001.
78. Kémoun P, Laurencin-Dalicieux S, Rue J, et al: Human dental follicle cells acquire cementoblast features under stimulation by BMP-2/-7 and enamel matrix derivatives (EMD) in vitro. Cell Tissue Res 329: 283-294, 2007.

79. Saito K, Konishi I, Nishiguchi M, Hoshino T and Fujiwara T: Amelogenin binds to both heparan sulfate and bone morphogenetic protein 2 and pharmacologically suppresses the effect of noggin. Bone 43: 371-376, 2008

80. Takayama T, Suzuki N, Narukawa M, Tokunaga T, Otsuka K and Ito K: Enamel matrix derivative stimulates core binding factor alpha1/Runt-related transcription factor-2 expression via activation of Smad1 in C2C12 cells. J Periodontol 76: 244-249, 2005.

81. Goldberg M, Six N, Decup F, et al: Bioactive molecules and the future of pulp therapy. Am J Dent 16: 66-76, 2003.

82. Larrain J, Bachiller D, Lu B, Agius E, Piccolo S and De Robertis EM: BMP-binding modules in chordin: a model for signalling regulation in the extracellular space. Development 127: 821-830, 2000

83. Zimmerman LB, De Jesús-Escobar JM and Harland RM: The Spemann organizer signal noggin binds and inactivates bone morphogenetic protein 4. Cell 86: 599-606, 1996.

84. Johnson DL, Carnes D, Steffensen B and Cochran DL: Cellular effects of enamel matrix derivative are associated with different molecular weight fractions following separation by size-exclusion chromatography. J Periodontol 80: 648-656, 2009.

85. Warotayanont R, Zhu D, Snead ML and Zhou Y: Leucine-rich amelogenin peptide induces osteogenesis in mouse embryonic stem cells. Biochem Biophys Res Commun 367: 1-6, 2008.

86. Li C, Shintani S, Terakado N, et al: Microvessel density and expression of vascular endothelial growth factor, basic fibroblast growth factor and platelet-derived endothelial growth factor in oral squamous cell carcinomas. Int J Oral Maxillofac Surg 34: $559-565,2005$

87. Johnstone S and Logan RM: The role of vascular endothelial growth factor (VEGF) in oral dysplasia and oral squamous cell carcinoma. Oral Oncol 42: 337-342, 2006.

88. Kerbel R and Folkman J: Clinical translation of angiogenesis inhibitors. Nat Rev Cancer 2: 727-739, 2002.

89. Deckers MM, Karperien M, van der Bent C, Yamashita T, Papapoulos SE and Löwik CW: Expression of vascular endothelial growth factors and their receptors during osteoblast differentiation. Endocrinology 141: 1667-1674, 2000.

90. Johnson RB, Serio FG and Dai X: Vascular endothelial growth factors and progression of periodontal diseases. J Periodontol 70: 848-852, 1999.

91. Mirastschijski U, Konrad D, Lundberg E, Lyngstadaas SP, Jorgensen LN and Agren MS: Effects of a topical enamel matrix derivative on skin wound healing. Wound Repair Regen 12: 100-108, 2004

92. Neeley WW II, Carnes DL and Cochran DL: Osteogenesis in an in vitro coculture of human periodontal ligament fibroblasts and human microvascular endothelial cells. J Periodontol 81: $139-149,2010$

93. Kauvar AS, Thoma DS, Carnes DL and Cochran DL: In vivo angiogenic activity of enamel matrix derivative. J Periodontol 81: 1196-1201, 2010.

94. Thoma DS, Villar CC, Carnes DL, Dard M, Chun YH and Cochran DL: Angiogenic activity of an enamel matrix derivative (EMD) and EMD-derived proteins: an experimental study in mice. J Clin Periodontol 38: 253-260, 2011.

95. Bartold PM and Raben A: Growth factor modulation of fibroblasts in simulated wound healing. J Periodontal Res 31: 205-216, 1996

96. Chang PC, Dovban AS, Lim LP, Chong LY, Kuo MY and Wang CH: Dual delivery of PDGF and simvastatin to accelerate periodontal regeneration in vivo. Biomaterials 34: 9990-9997, 2013.

97. Coimbra LS, Steffens JP, Rossa C Jr, Graves DT and Spolidorio LC Clopidogrel enhances periodontal repair in rats through decreased inflammation. J Clin Periodontol 41: 295-302, 2014.

98. Ojima Y, Mizuno M, Kuboki Y and Komori T: In vitro effect of platelet-derived growth factor-BB on collagen synthesis and proliferation of human periodontal ligament cells. Oral Dis 9: 144-151, 2003.

99. Saygin NE, Tokiyasu Y, Giannobile WV and Somerman MJ: Growth factors regulate expression of mineral associated genes in cementoblasts. J Periodontol 71: 1591-1600, 2000.

100. Strayhorn CL, Garrett JS, Dunn RL, Benedict JJ and Somerman MJ: Growth factors regulate expression of osteoblast-associated genes. J Periodontol 70: 1345-1354, 1999. 
101. Lynch SE, de Castilla GR, Williams RC, et al: The effects of short-term application of a combination of platelet-derived and insulin-like growth factors on periodontal wound healing. J Periodontol 62: 458-467, 1991.

102. van der Geer P, Hunter T and Lindberg RA: Receptor protein tyrosine kinases and their signal transduction pathways. Annu Rev Cell Biol 10: 251-337, 1994.

103. Matsuda N, Horikawa M, Watanabe M, Kitagawa S, Kudo Y and Takata T: Possible involvement of extracellular signal-regulated kinases $1 / 2$ in mitogenic response of periodontal ligament cells to enamel matrix derivative. Eur J Oral Sci 110: 439-444, 2002.

104. Gullberg D, Gehlsen KR, Turner DC, et al: Analysis of alpha 1 beta 1 , alpha 2 beta 1 and alpha 3 beta 1 integrins in cell-collagen interactions: identification of conformation dependent alpha 1 beta 1 binding sites in collagen type I. EMBO J 11: 3865-3873, 1992.

105. Hammacher A, Mellström K, Heldin CH and Westermark B: Isoform-specific induction of actin reorganization by platelet-derived growth factor suggests that the functionally active receptor is a dimer. EMBO J 8: 2489-2495, 1989.

106. Chong CH, Carnes DL, Moritz AJ, et al: Human periodontal fibroblast response to enamel matrix derivative, amelogenin and platelet-derived growth factor-BB. J Periodontol 77: 1242-1252, 2006.

107. Bouma-ter Steege JC, Mayo KH and Griffioen AW: Angiostatic proteins and peptides. Crit Rev Eukaryot Gene Expr 11: 319-334, 2001.

108. Traver D and Zon LI: Walking the walk: migration and other common themes in blood and vascular development. Cell 108: 731-734, 2002

109. Batouli S, Miura M, Brahim J, et al: Comparison of stem-cell-mediated osteogenesis and dentinogenesis. J Dent Res 82: 976-981, 2003.

110. Javed F, Al-Askar M, Al-Rasheed A and Al-Hezaimi K: Significance of the platelet-derived growth factor in periodontal tissue regeneration. Arch Oral Biol 56: 1476-1484, 2011.

111. Asahara T, Bauters C, Zheng LP, et al: Synergistic effect of vascular endothelial growth factor and basic fibroblas growth factor on angiogenesis in vivo. Circulation 92 (Suppl): II365-II371, 1995.

112. Goto F, Goto K, Weindel K and Folkman J: Synergistic effects of vascular endothelial growth factor and basic fibroblast growth factor on the proliferation and cord formation of bovine capillary endothelial cells within collagen gels. Lab Invest 69: 508-517, 1993.

113. Pepper MS, Ferrara N, Orci L and Montesano R: Potent synergism between vascular endothelial growth factor and basic fibroblast growth factor in the induction of angiogenesis in vitro. Biochem Biophys Res Commun 189: 824-831, 1992.

114. Mason JC, Lidington EA, Ahmad SR and Haskard DO: bFGF and VEGF synergistically enhance endothelial cytoprotection via decay-accelerating factor induction. Am J Physiol Cell Physiol 282: C578-C587, 2002.

115. Han L and Gotlieb AI: Fibroblast growth factor-2 promotes in vitro mitral valve interstitial cell repair through transforming growth factor- $\beta /$ Smad signaling. Am J Pathol 178 $119-127,2011$.

116. Schwartz Z, Carnes DL Jr, Pulliam R, et al: Porcine fetal enamel matrix derivative stimulates proliferation but not differentiation of pre-osteoblastic 2T9 cells, inhibits proliferation and stimulates differentiation of osteoblast-like MG63 cells and increases proliferation and differentiation of normal human osteoblast NHOst cells. J Periodontol 71: 1287-1296, 2000.

117. Canalis E, Centrella M and McCarthy T: Effects of basic fibroblast growth factor on bone formation in vitro. J Clin Invest 81: 1572-1577, 1988

118. Hurley MM, Abreu C, Harrison JR, Lichtler AC, Raisz LG and Kream BE: Basic fibroblast growth factor inhibits type I collagen gene expression in osteoblastic MC3T3-E1 cells. J Biol Chem 268: 5588-5593, 1993.

119. Mizutani S, Tsuboi T, Tazoe M, Koshihara Y, Goto S and Togari A: Involvement of FGF-2 in the action of Emdogain on normal human osteoblastic activity. Oral Dis 9: 210-217, 2003

120. Cheng T, Cao W, Wen R, Steinberg RH and LaVail MM: Prostaglandin E2 induces vascular endothelial growth factor and basic fibroblast growth factor mRNA expression in cultured rat Müller cells. Invest Ophthalmol Vis Sci 39: 581-591, 1998.
121. Sabbieti MG, Marchetti L, Abreu C, et al: Prostaglandins regulate the expression of fibroblast growth factor- 2 in bone. Endocrinology 140: 434-444, 1999.

122. Pickering JG, Ford CM, Tang B and Chow LH: Coordinated effects of fibroblast growth factor- 2 on expression of fibrillar collagens, matrix metalloproteinases and tissue inhibitors of matrix metalloproteinases by human vascular smooth muscle cells. Evidence for repressed collagen production and activated degradative capacity. Arterioscler Thromb Vasc Biol 17: 475-482, 1997.

123. Yanagita M, Kojima Y, Kubota M, et al: Cooperative effects of FGF-2 and VEGF-A in periodontal ligament cells. J Dent Res 93: 89-95, 2014.

124. Carpenter G and Cohen S: Epidermal growth factor. J Biol Chem 265: 7709-7712, 1990.

125. Cohen S: Nobel lecture. Epidermal growth factor. Biosci Rep 6: 1017-1028, 1986.

126. Furfaro F, Ang ES, Lareu RR, Murray K and Goonewardene M: A histological and micro-CT investigation in to the effect of NGF and EGF on the periodontal, alveolar bone, root and pulpal healing of replanted molars in a rat model-a pilot study. Prog Orthod 15: 2, 2014.

127. Guajardo G, Okamoto Y, Gogen $\mathrm{H}$, et al: Immunohistochemical localization of epidermal growth factor in cat paradental tissues during tooth movement. Am J Orthod Dentofacial Orthop 118: 210-219, 2000.

128. Keeve PL, Dittmar T, Gassmann G, Grimm WD, Niggemann B and Friedmann A: Characterization and analysis of migration patterns of dentospheres derived from periodontal tissue and the palate. J Periodontal Res 48: 276-285, 2013.

129. Pyrc K, Milewska A, Kantyka T, et al: Inactivation of epidermal growth factor by Porphyromonas gingivalis as a potential mechanism for periodontal tissue damage. Infect Immun 81: $55-64,2013$

130. Dereka XE, Markopoulou CE and Vrotsos IA: Role of growth factors on periodontal repair. Growth Factors 24: 260-267, 2006.

131. Lee J, Stavropoulos A, Susin C and Wikesjö UM: Periodontal regeneration: focus on growth and differentiation factors. Dent Clin North Am 54: 93-111, 2010.

132. Okuda K, Kawase T, Momose M, et al: Platelet-rich plasma contains high levels of platelet-derived growth factor and transforming growth factor-beta and modulates the proliferation of periodontally related cells in vitro. J Periodontol 74: 849-857, 2003.

133. Biscardi JS, Maa MC, Tice DA, Cox ME, Leu TH and Parsons SJ: c-Src-mediated phosphorylation of the epidermal growth factor receptor on Tyr845 and Tyr1101 is associated with modulation of receptor function. J Biol Chem 274: 8335-8343, 1999.

134. Zeldich E, Koren R, Dard M, Nemcovsky C and Weinreb M: EGFR in Enamel Matrix Derivative-induced gingival fibroblast mitogenesis. J Dent Res 87: 850-855, 2008.

135. Edwin F, Wiepz GJ, Singh R, et al: A historical perspective of the EGF receptor and related systems. Methods Mol Biol 327: 1-24, 2006.

136. Prenzel N, Zwick E, Daub H, et al: EGF receptor transactivation by G-protein-coupled receptors requires metalloproteinase cleavage of proHB-EGF. Nature 402: 884-888, 1999.

137. $\mathrm{Xu} \mathrm{KP}$, Yin J and Yu FS: SRC-family tyrosine kinases in wound- and ligand-induced epidermal growth factor receptor activation in human corneal epithelial cells. Invest Ophthalmol Vis Sci 47: 2832-2839, 2006.

138. Kutz SM, Higgins CE, Samarakoon R, et al: TGF-beta 1-induced PAI-1 expression is E box/USF-dependent and requires EGFR signaling. Exp Cell Res 312: 1093-1105, 2006.

139. Allen RR and Higgins PJ: Plasminogen activator inhibitor type-1 expression and the pathophysiology of TGF- $\beta 1$-induced epithelial-to-mesenchymal transition. Recent Res Dev Physiol 95: 918-931, 2004

140. Davies M, Robinson M, Smith E, Huntley S, Prime S and Paterson I: Induction of an epithelial to mesenchymal transition in human immortal and malignant keratinocytes by TGF-betal involves MAPK, Smad and AP-1 signalling pathways. J Cell Biochem 95: 918-931, 2005.

141. Lovschall H, Fejerskov O and Flyvbjerg A: Pulp-capping with recombinant human insulin-like growth factor I (rhIGF-I) in rat molars. Adv Dent Res 15: 108-112, 2001.

142. Okubo K, Kobayashi M, Takiguchi T, et al: Participation of endogenous IGF-I and TGF-beta 1 with enamel matrix derivative-stimulated cell growth in human periodontal ligament cells. J Periodontal Res 38: 1-9, 2003. 
143. Lee AZ, Jiang J, He J, Safavi KE, Spangberg LS and Zhu Q Stimulation of cytokines in osteoblasts cultured on ename matrix derivative. Oral Surg Oral Med Oral Pathol Oral Radiol Endod 106: 133-138, 2008.

144. MacNeil RL, D'Errico J, Strayhorn C, Pickrum H and Somerman MJ: Agents with periodontal regenerative potential regulate cell-mediated collagen lattice contraction in vitro. J Dent Res 75: 903-911, 1996.

145. Ikezawa K, Hart CE, Williams DC and Narayanan AS: Characterization of cementum derived growth factor as an insulin-like growth factor-I like molecule. Connect Tissue Res 36: 309-319, 1997.

146. Yonemura K, Raines EW, Ahn NG and Narayanan AS: Mitogenic signaling mechanisms of human cementum-derived growth factors. J Biol Chem 268: 26120-26126, 1993.
147. Xu L, Harada $\mathrm{H}$ and Taniguchi A: The effects of LAMP1 and LAMP3 on M180 amelogenin uptake, localization and amelogenin mRNA induction by amelogenin protein. J Biochem 144: 531-537, 2008.

148. Veis A, Tompkins K, Alvares K, et al: Specific amelogenin gene splice products have signaling effects on cells in culture and in implants in vivo. J Biol Chem 275: 41263-41272, 2000.

149. Boabaid F, Gibson CW, Kuehl MA, et al: Leucine-rich amelogenin peptide: a candidate signaling molecule during cementogenesis. J Periodontol 75: 1126-1136, 2004.

150. He J, Jiang J, Safavi KE, Spangberg LS and Zhu Q: Direct contact between enamel matrix derivative (EMD) and osteoblasts is not required for EMD-induced cell proliferation. Oral Surg Oral Med Oral Pathol Oral Radiol Endod 98: 370-375, 2004. 